\title{
Psychology of Forced Displacement and Migration: A systematic review of the scientific literature
}

\author{
Psicologia dos Deslocamentos e Migração Forçada: \\ uma revisão sistemática da literatura científica
}

\author{
Jonas CARVALHO e SILVA ${ }^{1}$ ID 0000-0002-0893-0283 \\ Júlia Sursis Nobre Ferro BUCHER-MALUSCHKE ${ }^{1}$ (D) 0000-0002-9194-8993
}

\begin{abstract}
Forced displacement is a research field in specific social and cultural contexts. This systematic review aims to identify, describe and analyze the research in Psychology of Forced Displacement and Migration published between 2006 and 2016. The databases selected were PsycINFO, Lilacs and SciELO following the criteria of Preferred Reporting Items for Systematic Reviews and Meta-Analyses, 2009. Content and methodology were assessed by Critical Appraisal Skill Programme. A total of 34 out of 491 articles fulfilled the eligibility criteria and were categorized in a framework that summarizes the main research questions and methodologies, including authors, research questions, units of analysis, dominant theories, and hypotheses. In conclusion, the framework helped to comprehend the general aspects of the existing research and pointed out interdisciplinary tendencies in the studies on this phenomenon.
\end{abstract}

Keywords: Forced displacement; Migration; Psychology; Review.

\section{Resumo}

Os deslocamentos forçados são uma área temática investigada em contextos culturais e sociais específicos. Esta revisão sistemática da literatura teve por objetivo identificar, descrever e analisar as pesquisas em Psicologia sobre os Deslocamentos e Migrações Forçadas publicadas no período de 2006 à 2016. Foram selecionadas as bases de dados PsycINFO, Lilacs e SciELO, conforme os critérios Preferred Reporting Items for Systematic Reviews and Meta-Analyzes, 2009. O conteúdo e a metodologia foram avaliados pelo Critical appraisal Skill Programme. Trinte e quatro dos 491 artigos obtidos atenderam aos critérios de elegibilidade e foram categorizados em uma matriz que sumariza as principais questões e metodologias

1 Universidade de Brasília, Instituto de Psicologia, Programa de Pós-Graduação em Psicologia Clínica e Cultura. Campus Universitário Darcy Ribeiro, Asa Norte, 70297-400, Brasília, DF, Brasil. Correspondência para/Correspondence to: J. CARVALHO e SILVA. E-mail: <carvalho707@gmail.com>.

Article based on the doctoral dissertation of J. CARVALHO e SILVA, entitled "Impactos individuais e contextuais do deslocamento forçado na comunidade". Universidade de Brasília, 2018

Como citar este artigo/How to cite this article

Carvalho e Silva, J., \& Bucher-Maluschke, J. S. N. F. (2018). Psychology of Forced Displacement and Migration: A systematic review of the scientific literature. Estudos de Psicologia (Campinas), 35(2), 127-136. http://dx.doi.org/10.1590/1982-02752018000200002 
das pesquisas. Ela também apresenta os autores, perguntas, unidades de análise, teorias dominantes e hipóteses. À guisa de conclusão a matriz possibilitou compreender os aspectos gerais das pesquisas existentes em Psicologia e apontou tendências interdisciplinares nos estudos sobre esse fenômeno.

Palavras-chave: Deslocamentos forçados; Migração; Psicologia; Revisão.

The migration phenomenon has lately been in the spotlight of international politics and a challenge for psychology in modern societies. This systematic review aims to identify, describe and analyze the main research issues and methodologies in Psychology on Forced Displacement and Migration (FDM) indexed in databases that disseminate scientific productions in electronic and printed format.

There are certainly multiple contributions to this complex phenomenon. The compendium developed by Brettell \& Hollifield (2015) on the migration theory across disciplines describes the research questions and methodologies of Anthropology, Demography, Economics, Geography, History, Law, Political Sciences, and Sociology, without including Psychology as a field of knowledge in the area. Meanwhile, the American Psychological Association (APA) has published the presidential report of the task force on immigration (American Psychological Association, 2012) entitled Crossroads: The Psychology of immigration in the new century.

The APA recommends a psycho-socioecological approach, based upon Urie Bronfenbrenner's bioecological model (Bronfenbrenner \& Morris, 2007), and reports a moment of intense migratory flows, resulting from polysemic transformations that pervade crises in the economic system aggregated to factors of political and cultural institutions. In addition, these disciplines mentioned in the compendium Brettell \& Hollifield (2015) also point to the interdependence of levels of human ecology from individual to more complex aspects.

The following questions were considered in this review: in Psychology, what are the research questions and methodologies in the scientific literature on FDM? Based on the selection of the articles in the 3 databases using the PRISMA criteria and the analysis of the results, following the 10 items of the CASP systematic review checklist, it was possible to examine the experiences of forced geographic displacement as they can be associated with different transversality issues and consequences.

Forced Displacement and Migration is often accompanied by relocation, which knowingly leads to adaptation problems to the new environment and physical and mental health issues (Siriwardhana \& Stewart, 2013). The participation of Psychology in the current context of the migratory phenomenon and the particularities attributed to FDM, as well as the questions, units of analysis, dominant theories, and hypotheses of the selected articles will be addressed. Finally, directions for future research on FDM are suggested.

In this sense, previous to the APA report, European and North American Clinical Psychology have conducted scientific studies that deal with cultural adaptation and acculturation of migrants (Berry, 2004; Phinney, 2004). Interdisciplinarity is perceived as an important aspect for the understanding of the different theoretical and methodological approaches of migration.

In Brazil, similar phenomena have even greater force given the breadth of the territory. There is a greater tendency in the literature to study internal migration, particularly mobility from more impoverished regions to improve working conditions or for family reasons (Carvalho \& Martins, 2016). Thus, other patterns such as forced displacement, compulsory migration, and environmental refuge can be added under the umbrella of migration theory.

This relatively contemporary view (Cecconello \& Koller, 2003) has promoted a reconciliation with migration studies such as forced displacement. Based on the relative interdisciplinary fluency, theoretical perspectives from cultural geography, including linguistics, sociology and part of psychology (Carvalho e Silva \& Ertzogue, 2015), 
are included. A broad discussion that aggregates the environmental, cultural and psychological impact on people affected by specific mobility could be promoted.

\section{Method}

This empirical and evidence-based literature review was based on extensive research. The databases PsycINFO, Lilacs and SciELO were used. Keywords were defined in controlled vocabularies in English to expand coverage of articles in journals without Brazilian authors, such as "Displacement AND Psychology" and "Forced Migration AND Psychology". The most important word was "Psychology", as it correlated the phenomenon with the study area, and the measurements were "displacement" and "forced migration", followed by "AND".

In the databases, the terms were searched for in the titles, keywords and abstracts. For the inclusion criteria, the articles had to be peerreviewed in English, Spanish or Portuguese and written by authors in psychology or published by journals of psychology. Articles published more than 10 years ago were excluded.

The samples were selected by reading the abstracts for their relevance to the area on forced displacement and migration. A large number of manuscripts were retained at this stage for possible inclusion in the theoretical review (except for the systematic review, as they provided no evidence). In this sense, all articles were evaluated by eligibility criteria in the systematic review. The exclusion criteria were as follows: (1) business migration (e.g. migration in oil companies in Scandinavian countries); (2) migrations in other historical contexts (e.g., Nazi regime, diaspora); (3) non-forced migration (e.g. migration of health professionals, migration as a secondary theme); (4) languages other than Portuguese, Spanish or English; (5) incomplete text (after contacting the first and/or second author); (6) lack of data; (7) literary studies.

The next three inclusion and exclusion criteria require further explanation. First, a number of articles were excluded because they reported psychological repercussions in broader contexts, identifying FDM as one of the contributing factors to the difficulties. Therefore, migration was assessed as a dependent variable, whereas FDM as independent variables.

Finally, there were some concessions regarding the methodological rigor for examining the results in the CASP systematic review checklist: some studies presented few measurable data or from specific populations. Given the scarcity of research, especially with children and families, it was agreed to retain those relevant to the context of the topic, using the PRISMA selection criteria, which allows the inclusion of additional samples identified in other sources (Figure 1). A total of 34 articles were selected for the analysis as we will see below.

\section{Results}

The selected manuscripts were submitted to PRISMA 2009 (Preferred Reporting Items for Systematic Reviews and Meta-Analyses) and assessed by the scales of the Critical appraisal skill program (CASP). All included articles received the necessary scores for levels A (9 to 10 positive items) and $B$ ( 5 positive items - moderate bias) in the second instrument. Therefore, the information was organized in an organizational chart for the literature review.

Several studies have examined FDM in migrant children and adolescents and schools as mediators of conflicts inherent to this process: assessment of migrant children (Schölmerich, Leyendecker, Citlak, Caspar, \& Jäkel, 2008); relationship between rural and urban migrant children (Shi, Qian, Lu, Plucker, \& Lin, 2012). These samples were also extended to teachers, parents, and the school community (Valdez, Lewis Valentine, \& Padilla, 2013).

Other studies have analyzed mental health (Neto, 2009, 2010), the psychopathological trends of migrants (Blanco \& Amarís, 2014; Mosquera, Lozano, Gutiérrez, Robayo, \& Leal, 2010; Sacipa, 


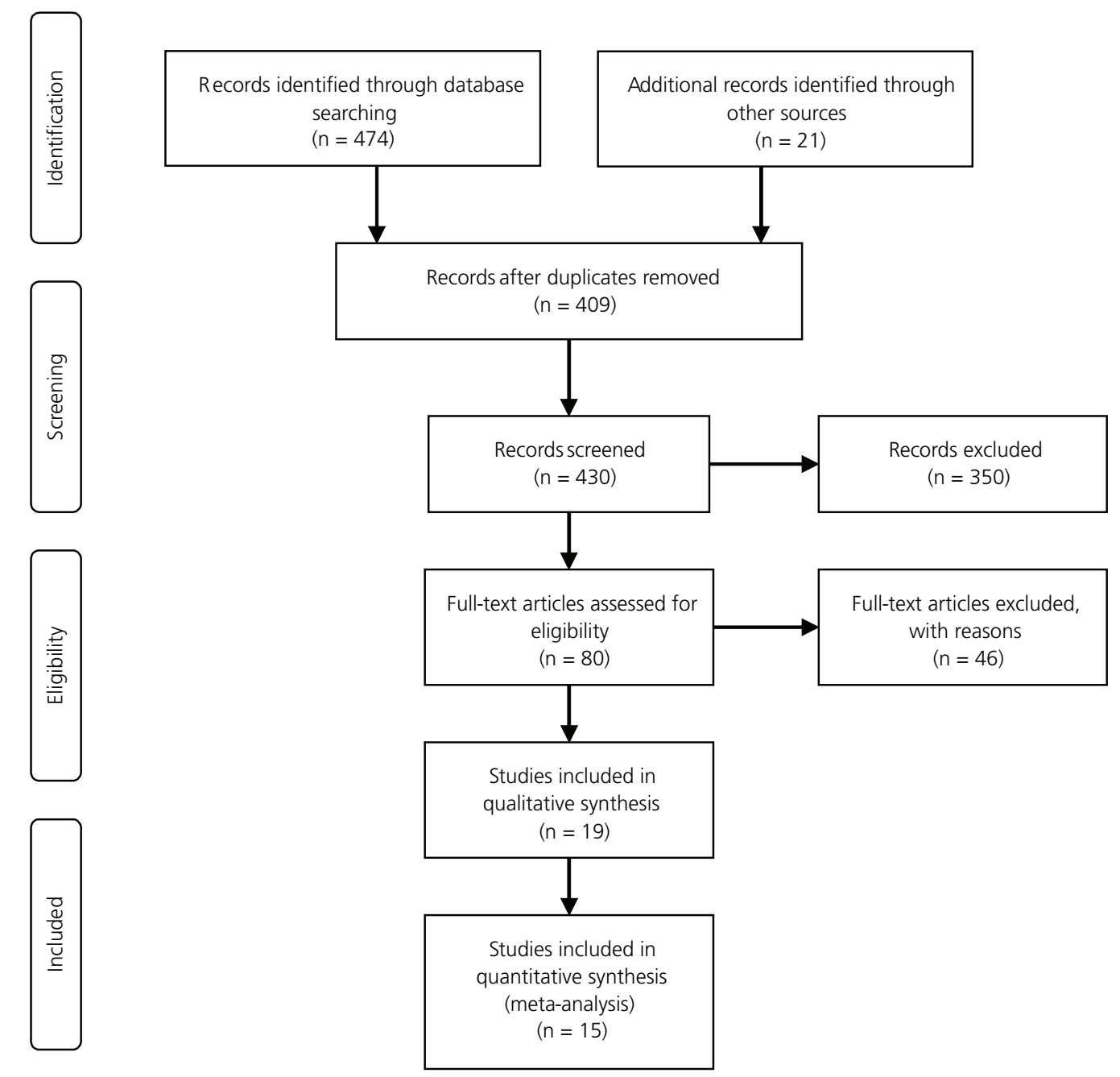

Figure 1. Organizational chart from the different phases of the review.

Note: CC-BY license.

Source: PRISMA Statement http://prismastatemen.org/PRISMAStatement/PRISMAStatement.aspx

Vidales, Galindo, \& Tovar, 2007; Salazar, Giraldo, \& Padilla, 2011) and intergroup relations - gender, e.g., Blanco \& Amarís (2014); cultural identity, e.g., Tummala-Narra (2014). There was a study that investigated the friendship of Brazilian residents abroad (Garcia, Neto, \& Góes, 2014) and a followup (Mähönen \& Jasinskaja-Lahti, 2012).

The studies with adult samples assessed health relations (Coutinho \& Oliveira, 2006), quality of life (Urzúa, Vega, Jara, Trujillo, \& Muñoz, 2015), violence (Power, 2016), migration policies (Valdez et al., 2013), and gender (Sezgin, 2016). The clinical works, psychoanalytic and systemic studies, carried
Indursky \& Conte, 2015; Tummala-Narra, 2014; Walsh \& Shulman, 2007) and emphasized cultural and family transmission (Daure, Reyverand-Coulon, \& Forzan, 2014).

The research in Latin America dealt mainly with the processes experienced by forced displacement from armed conflicts in the Colombian Amazon (Avendaño-Villa, Cortés-Peña, \& Guerrero-Cuentas, 2015; Díaz, Molina, \& Marín, 2015; Mora \& Matínez, 2014; Mosquera et al., 2010; Rangel \& Losada, 2011; Sacipa et al., 2007; Salazar et al., 2011; Vargas \& Toro, 2016). In parallel, studies such as a clinical case in Brazil (Ferreira, 2015) and another on the quality of life of Peruvian and 
Colombian immigrants in northern Chile were identified (Urzúa et al., 2015).

The review pointed to violence as the preponderant cause of migratory processes, except for two articles on environmental disasters. One focused on women's mental health after an earthquake (Sezgin, 2016), and another qualitative study on the experiences of displaced survivors of Hurricane Katrina in 2005 (Tuason, Güss, \& Carroll, 2012).

As for the publication years, the search covered state of the art studies over the past 10 years (2006-2016). Most publications were from 2010 (11.1\%), 2012 (11.1\%), 2014 (16.6\%), 2015 (22.2\%) and 2016 (11.1\%). No articles were found in 2006 and the others ranged from 1 to 3 manuscripts in the selected databases.

\section{Discussion}

The framework of the articles (Table 1) was developed using the organizational chart. This is a usual procedure for a more comprehensive view of the selected bibliographic material and it synthesizes the available knowledge on the subject from different currents of psychology.

\section{Methodological framework of psychology research and FDM}

Research questions: the research questions were formulated from the objectives in the organizational chart. They focused on migrant populations (Garcia et al., 2014; Sacipa et al., 2007; Schölmerich et al., 2008), host populations (Murray \& Marx, 2013) and experiences (Sonn, Ivey, Baker, \& Meyer, 2015) from specific populations (countries, ethnicity, etc.), as well as permanence in the host community (Sezgin, 2016; Valdez et al., 2013). Questions that addressed mediation of institutions - What is the school's role in acculturation and construction of subjectivity of migrant adolescents? (Mora \& Matínez, 2014; Shoshani, Nakash, Zubida, Harper, \& Harper, 2015), investigation of the consequences of migration for the family (Daure et al., 2014), what promotes the construction of identity during and after migration (Dandy \& PePua, 2013; Mähönen \& Jasinskaja-Lahti, 2012; Tummala-Narra, 2014), and the relation to the bio-socio-demographic profiles of the populations (Coutinho \& Oliveira, 2006).

Questions related to mental health problems (Neto, 2009), psychopathologies (Salazar et al., 2011), and relevant inquiries in psychoanalytic clinical language (Ferreira, 2015) were also addressed. Two articles addressed the quality of life of migrants (Mosquera et al., 2010; Urzúa et al., 2015), and more specific questions about the consequences (e.g., discrimination) of experiences and memories of victims of FDM based on issues for the promotion of migration policies (Brenick, Titzmann, Michel, \& Silbereisen, 2012; Denov \& Blanchet-Cohen, 2016; Díaz et al., 2015; Power, 2016; Rangel \& Losada, 2011). Issues related to women being the main victims of FDM (Blanco \& Amarís, 2014; Neto, 2009) and the experiences of people displaced by environmental disasters (Tuason et al., 2012) were addressed.

Units of analysis - The units of analysis were extracted from the field "Participants: identify" of the organizational chart. Regarding the levels, all articles were micro: individuals, family, groups (Brettell \& Hollifield, 2015). This finding points to a significant approximation between the disciplines Psychology and Anthropology.

The prevalent units of analysis were groups (10) and ethnic groups (6). One article analyzed children (Schölmerich et al., 2008), teachers, parents and students (5), families (2), individuals (3) and adolescents (1) (Neto, 2010).

Dominant theories - to establish the dominant theories of the revision we observed which themes were more often repeated in the bibliographical references of each article. The great number of psychoanalytic (5), cultural (5), ethnic-racial (4) and human rights (3) theories was remarkable. Other theories appeared less frequently as indicated in framework.

Hypotheses of the samples - The filling out in the fields "Main Results" and "Conclusion" of 
Table 1

Methodological framework of the research on Psychology and Migration

1 of 2

\begin{tabular}{|c|c|c|c|c|}
\hline Authors & Question & Units of analysis & Dominant theories & Hipotheses of the samples \\
\hline $\begin{array}{l}\text { Denov and Blanchet- } \\
\text { Cohen (2016) }\end{array}$ & $\begin{array}{l}\text { How can experiences in } \\
\text { times of war be subjective? }\end{array}$ & Individuals & Behavioral theories & $\begin{array}{l}\text { Power relations at structural, } \\
\text { organizational and individual } \\
\text { levels. }\end{array}$ \\
\hline Power (2016) & What is migration? & Groups & Cultural studies & $\begin{array}{l}\text { It is a legitimized, historical- } \\
\text { cultural response to suffering. }\end{array}$ \\
\hline $\begin{array}{l}\text { Vargas and Toro } \\
\text { (2016) }\end{array}$ & $\begin{array}{l}\text { What contributes to the } \\
\text { education of the displaced } \\
\text { person? }\end{array}$ & $\begin{array}{l}\text { Teachers, parentes and } \\
\text { students }\end{array}$ & Human rights & $\begin{array}{l}\text { The process of continuous } \\
\text { training of teachers. }\end{array}$ \\
\hline $\begin{array}{l}\text { Sezgin (2016); Valdez } \\
\text { et al. (2013) }\end{array}$ & $\begin{array}{l}\text { Why do unauthorized } \\
\text { people remain in the } \\
\text { community? }\end{array}$ & Ethnic groups & Migration theories & $\begin{array}{l}\text { Family, community and } \\
\text { interrelated sociopolitical factors. }\end{array}$ \\
\hline Ferreira (2015) & What stimulates psychosis? & Individual & Psychoanalysis & Segregation from social life. \\
\hline $\begin{array}{l}\text { Avendaño-Villa et al. } \\
\text { (2015) }\end{array}$ & $\begin{array}{l}\text { Which technology helps } \\
\text { academic performance? }\end{array}$ & $\begin{array}{l}\text { Teachers, parentes and } \\
\text { students }\end{array}$ & Social construtivism & $\begin{array}{l}\text { Prosocial behavior, Information } \\
\text { Technology and Communication. }\end{array}$ \\
\hline $\begin{array}{l}\text { Indursky and Conte } \\
\text { (2015) }\end{array}$ & $\begin{array}{l}\text { What leads to catastrophic } \\
\text { symptoms? }\end{array}$ & Family & Psychoanalysis & Exile. \\
\hline Shoshani et al. (2015) & $\begin{array}{l}\text { What is the school's role } \\
\text { for the acculturation of } \\
\text { migrant adolescents? }\end{array}$ & Students & Cultural adaptation & $\begin{array}{l}\text { Measure the relationships of } \\
\text { school development with mental } \\
\text { health and risk behaviors. }\end{array}$ \\
\hline Sonn et al. (2015) & $\begin{array}{l}\text { Which experiences } \\
\text { influence identity? }\end{array}$ & Groups & Ethnic-racial theories & $\begin{array}{l}\text { Cultural and psychological } \\
\text { dimensions. }\end{array}$ \\
\hline $\begin{array}{l}\text { Blanco and Amarís } \\
\text { (2014) }\end{array}$ & $\begin{array}{l}\text { Who are the greatest } \\
\text { victims of displacement? }\end{array}$ & Women & Feminist theories & Women. \\
\hline Daure et al. (2014) & $\begin{array}{l}\text { What is the consequence } \\
\text { of migration for the family? }\end{array}$ & Families & Sistemic theory & $\begin{array}{l}\text { The migratory event causes a } \\
\text { certain imbalance in the family } \\
\text { system. }\end{array}$ \\
\hline Garcia et al. (2014) & $\begin{array}{l}\text { How are the friendships of } \\
\text { migrants? }\end{array}$ & Ethnic groups & Cultural adaptation & $\begin{array}{l}\text { The friend is a guide and } \\
\text { socializing agent in the new } \\
\text { environment. }\end{array}$ \\
\hline $\begin{array}{l}\text { Tummala-Narra } \\
\text { (2014) }\end{array}$ & $\begin{array}{l}\text { How does cultural identity } \\
\text { develop in victims of } \\
\text { violence? }\end{array}$ & Individual & Psychoanalysis & $\begin{array}{l}\text { They are dealt in complex ways } \\
\text { in the context of interpersonal } \\
\text { violence. }\end{array}$ \\
\hline $\begin{array}{l}\text { Dandy and Pe-Pua } \\
\text { (2013) }\end{array}$ & $\begin{array}{l}\text { What drives intergroup } \\
\text { relations? }\end{array}$ & Ethnic groups & Ethnic-racial theories & $\begin{array}{l}\text { They are complex with } \\
\text { stress caused by threats and } \\
\text { deprivations. }\end{array}$ \\
\hline Brenick et al. (2012) & $\begin{array}{l}\text { Who perceives } \\
\text { discrimination better? }\end{array}$ & Ethnic groups & Ethnic-racial theories & $\begin{array}{l}\text { Groups with greater in-group } \\
\text { orientation. }\end{array}$ \\
\hline $\begin{array}{l}\text { Mähönen and } \\
\text { Jasinskaja-Lahti } \\
\text { (2012) }\end{array}$ & $\begin{array}{l}\text { When does cultural identity } \\
\text { develop? }\end{array}$ & & Cultural studies & Post-migration period. \\
\hline
\end{tabular}




\begin{tabular}{|c|c|c|c|c|}
\hline Authors & Question & Units of analysis & Dominant theories & Hipotheses of the samples \\
\hline $\begin{array}{l}\text { Tuason et al. } \\
\text { (2012) }\end{array}$ & $\begin{array}{l}\text { What are the experiences } \\
\text { of people displaced by } \\
\text { environmental disasters? }\end{array}$ & Groups & Critical theory & $\begin{array}{l}\text { The impact of cultural differences on } \\
\text { the survivor's "home" compared to } \\
\text { the new place they inhabit. }\end{array}$ \\
\hline Shi et al. (2012) & $\begin{array}{l}\text { What is the ratio time in } \\
\text { test results? }\end{array}$ & Students & Personality theories & $\begin{array}{l}\text { Children with longer migration times } \\
\text { perform better in thinking tests. }\end{array}$ \\
\hline $\begin{array}{l}\text { Salazar et al. } \\
\text { (2011) }\end{array}$ & $\begin{array}{l}\text { What influences reactive } \\
\text { behaviors? }\end{array}$ & & DSM & Psychopathological trends. \\
\hline Neto (2010) & $\begin{array}{l}\text { What contributes to mental } \\
\text { health? }\end{array}$ & Adolescents & Cultural adaptation & Socio-cultural adaptation. \\
\hline Harlem (2010) & $\begin{array}{l}\text { What is a dissociative state } \\
\text { in exile? }\end{array}$ & Individuals & Psychoanalysis & $\begin{array}{l}\text { Gaps between the versions of } \\
\text { dissociated self states from time, } \\
\text { physical spaces and relationships. }\end{array}$ \\
\hline $\begin{array}{l}\text { Mosquera et al. } \\
(2010)\end{array}$ & $\begin{array}{l}\text { Which variables affect the } \\
\text { quality of life of patients } \\
\text { with PTSD? }\end{array}$ & Micro/groups & DSM & $\begin{array}{l}\text { Sex, marital status, employment } \\
\text { status, education, occupation, time, } \\
\text { type and cause of displacement, and } \\
\text { self-perception. }\end{array}$ \\
\hline Neto (2009) & $\begin{array}{l}\text { Who has more mental } \\
\text { health problems? }\end{array}$ & Adolescents & Cultural adaptation & Women. \\
\hline $\begin{array}{l}\text { Sacipa et al. } \\
\text { (2007) }\end{array}$ & $\begin{array}{l}\text { What is the psychosocial } \\
\text { effect on adversity? }\end{array}$ & Groups & Human rights & $\begin{array}{l}\text { Silence is a psychosocial effect of the } \\
\text { victims of armed conflict. }\end{array}$ \\
\hline $\begin{array}{l}\text { Walsh and } \\
\text { Shulman (2007) }\end{array}$ & $\begin{array}{l}\text { What is the meaning of } \\
\text { self? }\end{array}$ & Social status & Psychoanalysis & $\begin{array}{l}\text { Experiencing the feelings of the } \\
\text { mourning process. }\end{array}$ \\
\hline $\begin{array}{l}\text { Coutinho and } \\
\text { Oliveira (2006) }\end{array}$ & $\begin{array}{l}\text { Which are the implications } \\
\text { of the bio-sociodemographic } \\
\text { profile? }\end{array}$ & Ethnic groups & Cultural adaptation & $\begin{array}{l}\text { The "systemic invisibility" of FDM } \\
\text { compared to other types of migration. }\end{array}$ \\
\hline
\end{tabular}

the organizational chart guided the development of the hypotheses of the samples. Articles based on psychoanalytic theories have generally addressed the complexity of identity processes (Ferreira, 2015; Harlem, 2010; Tummala-Narra, 2014), which may lead to psychic suffering (mourning, e.g. Walsh \& Shulman, 2007). As a result, cultural adaptation theories suggest that this process depends on socializing agents (Garcia et al., 2014), sociocultural visibility (Coutinho \& Oliveira, 2006; Neto, 2009), permanence authorization (Urzúa et al., 2015) and gender relations (Neto, 2009). Studies based on ethnic-racial theories point out that preconceived attitudes (Murray \& Marx, 2013) influence identity (Sonn et al., 2015) in group relations and cause high levels of discrimination (Brenick et al., 2012; Dandy \& Pe-Pua, 2013). Studies based on Human Rights theories suggest that silence is a psychosocial effect (Sacipa et al., 2007) and it can be mediated (Vargas \& Toro, 2016) for better knowledge about the social being of the migrant population (Rangel \& Losada, 2011). 
The other articles proposed a significant diversity of hypotheses, which are related to the systems and dominant theories of each one. In general, the theories indicate damage to mental health and misfits in various systems that could be caused by the migratory process.

\section{Final Considerations}

The contribution of the study was the systematized evidence of the state of the art concerning the theme of this investigation. As discussed in the previous sections, the major contribution of scientific studies on FDM would be if researchers focused on engaging the experiences associated with the adjustment to the new environment. It would also be relevant if research findings were related to socio-cultural diversity, as is the case of Brazil given the size of the territory. This would allow the hypotheses to be easily compared.

This article has been able to include psychology in the methodological framework of the Migration Theory in the light of the APA recommendations. It is important to emphasize the need for further research that guarantees human rights and the promotion of public policies for the populations affected by specific mobility taking into account the characteristics of each region and culture.

\section{Contributors \\ All authors contributed to the study's design, data analysis and final writing. \\ References \\ American Psychological Association (2012). Report of the APA task force on immigration: Executive summary. Washington. \\ Avendaño-Villa, I., Cortés-Peña, O. F., \& Guerrero-Cuentas, H. (2015). Competencias sociales y tecnologías de la información y la comunicación como factores asociados al desempeño en estudiantes de básica primaria con experiencia de desplazamiento forzado. Diversitas: Perspectivas en Psicología, 11(1), 13-36.}

Berry, J. W. (2004). Migração, aculturação e adaptação. In I. B. Güntert \& M. Chinalli (Orgs.), Psicologia, E/ imigração e cultura. São Paulo: Casa do Psicólogo.

Blanco, A., \& Amarís, M. (2014). La ruta psicosocial del desplazamiento: una perspectiva de género. Universitas Psychologica, 13(2), 661-679. http://dx.doi. org/10.11144/Javeriana.UPSY13-2.rpdu

Brenick, A., Titzmann, P. F., Michel, A., \& Silbereisen, R. K. (2012). Perceptions of discrimination by young diaspora migrants: Individual- and school-level associations among adolescent ethnic German immigrants. European Psychologist, 17(2), 105-119. http://dx.doi.org/10.1027/1016-9040/a000118

Brettell, C. B., \& Hollifield, J. F. (2015). Migration theory: talking across disciplines. In C. B. \& H. J. F. Brettell (Orgs.), Migration Theory (3th ed.). New York: Routledge.

Bronfenbrenner, U., \& Morris, P. A. (2007). The bioecological model of human development. In Handbook of Child Psychology (pp.793-828). Hoboken: John Wiley \& Sons. http://dx.doi.org/10.1002/9780470147658. chpsy0114

Carvalho, A. R., \& Martins, F. C. (2016). A psychological perspective on immigration: the reasons and hardships of migrating to Brazil's capital, Brasília. International Journal of Migration, Health and Social Care, 12(3), 216-224. http://dx.doi.org/10.1108/ IJMHSC-06-2015-0021

Carvalho e Silva, J., \& Ertzogue, M. H. (2015). Cosmologia, paisagem, lugar e o método fenomenológico: possíveis reflexões em uma cidade impactada por barragem. PRACS: Revista de Humaninadades do Curso de Ciências Sociais da UNIFAP, 8(1), 11-24.

Cecconello, A. M., \& Koller, S. H. (2003). Inserção ecológica na comunidade: uma proposta metodológica para o estudo de famílias em situação de risco. Psicologia: Reflexão e Critica, 16(3), 515-524. http://dx.doi. org/10.1590/S0102-79722003000300010

Coutinho, M. P. L., \& Oliveira, M. X. (2006). Tendências comportamentais frente à saúde de imigrantes brasileiros em Portugal. Psicologia \& Sociedade, 22(3), 548-557.

Dandy, J., \& Pe-Pua, R. (2013). Beyond mutual acculturation: Intergroup relations among immigrants, Anglo-Australians, and Indigenous Australians. Zeitschrift fur Psychologie/Journal of Psychology, 221(4), 232-241. http://dx.doi.org/10.1027/21512604/a000153

Daure, I., Reyverand-Coulon, O., \& Forzan, S. (2014). Relações familiares e migração: um modelo teórico-clínico em psicologia. Psicologia Clínica, 26(1), 91-108. http://dx.doi.org/10.1590/S0103-566520 14000100007

Denov, M., \& Blanchet-Cohen, N. (2016). Trajectories of violence and survival: turnings and adaptations in the 
lives of two war-affected youth living in Canada. Peace and Conflict: Journal of Peace Psychology, 22(3), 236245. http://dx.doi.org/10.1037/pac0000169

Díaz, V. E., Molina, A. N., \& Marín, M. A. (2015). Las pérdidas y los duelos en personas afectadas por el desplazamiento forzado. Pensamiento Psicológico, 13(1), 65-80. http://dx.doi.org/10.11144/Javerianacali. PPSI13-1.pdpa

Ferreira, A. P. (2015). Migração, rupturas psíquicas e espaços terapêuticos. Psicologia USP, 26(2), 193-198.

Garcia, A., Neto, C. B., \& Góes, D. C. (2014). Amizades de brasileiros residindo no exterior: adaptação e percepção do país estrangeiro. Psicologia Argumento, 32(79), 141-148. http://dx.doi.org/10.7213/psicol.. argum.32.s02.A013

Harlem, A. (2010). Exile as a dissociative state: When a self is "lost in transit". Psychoanalytic Psychology, 27(4), 460-474. http:// dx.doi.org/10.1037/a0020755

Indursky, A. C., \& Conte, B. S. (2015). Trabalho psíquico do exílio: o corpo à prova da transição. Ágora: Estudos em Teoria Psicanalítica, 18(2), 273-288. http://dx.doi. org/10.1590/S1516-14982015000200008

Mähönen, T. A., \& Jasinskaja-Lahti, I. (2012). Anticipated and perceived intergroup relations as predictors of immigrants' identification patterns a follow-up study. European Psychologist, 17(2), 120-130. http://dx.doi. org/10.1027/1016-9040/a000114

Mora, F. M. G., \& Matínez, D. E. V. (2014). Incidencia de la educación inicial en la construcción de subjetividad en niños y niñas de 3 a 5 años en situación de desplazamiento en un jardín en Bogotá en el sector de Bosa. Psicogente, 17(32), 307-322.

Mosquera, M. S., Lozano, F. S. F., Gutiérrez, V. F. M., Robayo, M. F., \& Leal, J. F. S. (2010). Prevalencia del transtorno de estrés post traumático en población en situación de desplazamiento en la localidade de ciudad Bolívar Bogotá, Colombia, 2007. Psychologia: Avances de La Disciplina, 4(2), 83-97.

Murray, K. E., \& Marx, D. M. (2013). Attitudes toward unauthorized immigrants, authorized immigrants, and refugees. Cultural Diversity and Ethnic Minority Psychology, 19(3), 332-341. http://dx.doi.org/10.1037/ a0030812

Neto, F. (2009). Predictors of mental health among adolescents from immigrant families in Portugal. Journal of Family Psychology, 23(3), 375-385. http:// dx.doi.org/10.1037/a0015831

Neto, F. (2010). Mental health among adolescents from returned Portuguese immigrant families from North America. North American Journal of Psychology, 69(3), 131-139. http://dx. doi.org/10.1024/1421-0185/ a000015

Phinney, J. S. (2004). Formação da identidade de grupo e mudança entre migrantes e seus filhos. In M. Güntert,
I. B. Chinalli (Orgs.), Piscologia, Elimigração e cultura (pp. 47-60). São Paulo: Casa do Psicólogo.

Power, S. A. (2016). A violent past but a peaceful present: The cultural psychology of an Irish recession. Peace and Conflict: Journal of Peace Psychology, 22(1), 60-66. http://dx.doi.org/10.1037/pac0000161

Rangel, K. J. C., \& Losada, M. F. T. (2011). Significados de justicia: una reflexión a partir de un estudio con personas en situación de desplazamiento forzado por la violencia. Sociedad y Economía: Revista de la Facultad de Ciencias Sociales y Económicas-Univalle, 20, 268-290.

Sacipa, S., Vidales, R., Galindo, L., \& Tovar, C. (2007). Psychosocial accompaniment to liberate the suffering associated with the experience of forced displacement. Universitas Psichologica, 60(4), 305-309. http://dx. doi. org/10.1227/01.NEU.0000255416.55560.D2

Salazar, J. A. A., Giraldo, M. P., \& Padilla, L. D. T. (2011). Tendencias psicopatológicas en personas desplazadas y re-asentadas en el departamento del quindío entel el 2005 y el 2011. El Ágora USB, 11(2), 279-296.

Schölmerich, A., Leyendecker, B., Citlak, B., Caspar, U., \& Jäkel, J. (2008). Assessment of migrant and minority children. Zeitschrift für Psychologie/Journal of Psychology, 216(3), 187-194. http://dx.doi.org/10. 1027/0044-3409.216.3.187

Sezgin, U. (2016). Women's disaster-related mental health: The decision to leave or to stay after an earthquake, Traumatology, 22(1), 40-47.

Shi, B., Qian, M., Lu, Y., Plucker, J. a., \& Lin, C. (2012). The relationship between migration and Chinese children's divergent thinking. Psychology of Aesthetics, Creativity, and the Arts, 6(2), 106-111. http://dx.doi. org/10.1037/a0028023

Shoshani, A., Nakash, O., Zubida, H., Harper, R. A., \& Harper, R. A. (2015). School engagemente, acculturation, and mental health among migrant adolescents in Israel. School Psychology Quarterly, 1(1), 1-31. http://dx.doi.org/http://dx.doi.org/10.1037/ spq0000133

Siriwardhana, C., \& Stewart, R. (2013). Forced migration and mental health: Prolonged internal displacement, return migration and resilience. International Health, 5(1), 19-23. http://dx.doi.org/10.1093/inthealth/ihs0 14

Sonn, C. C., Ivey, G., Baker, A., \& Meyer, K. (2015). Post-Apartheid South African immigrants in Australia: Negotiating displacement, identity, and belonging. Qualitative Psychology, 4(1), 41-54. http://dx.doi. org/10.1037/qup0000039

Tuason, M. T. G., Güss, C. D., \& Carroll, L. (2012). The disaster continues: A qualitative study on the experiences of displace Hurricane Katrina survivors. Professional Psychology: Research \& Practice, 43(4), 288-297. http://dx.doi.org/10.1037/a0028054 
Tummala-Narra, P. (2014). Cultural identity in the context of trauma and immigration from a psychoanalytic perspective. Psychoanalytic Psychology, 31(3), 396-409. http://dx.doi.org/10.1037/a0036539

Urzúa, A., Vega, M., Jara, A., Trujillo, S., \& Muñoz, R. (2015). Calidad de vida percibida en inmigrantes sudamericanos en el norte de Chile. Terapia Psicologica, 33(2), 139-156. http://dx.doi.org/10.4067/S0718-48 082015000200008

Valdez, C. R., Lewis Valentine, J., \& Padilla, B. (2013). "Why we stay": immigrants' motivations for remaining in communities impacted by anti-immigration policy. Cultural Diversity \& Ethnic Minority Psychology, 19(3), 279-87. http://dx.doi.org/10.1037/a0033176
Vargas, N. H. D., \& Toro, P. L. (2016). Autopercepción de saberes y prácticas sobre educación y desplazamiento forzado en docentes de Cali, Colombia. Revista Colombiana de Psicología, 25(1), 155-173. http://dx. doi.org/10.15446/rcp.v25n1.49971

Walsh, S. D., \& Shulman, S. (2007). Splits in the self following immigration: An adaptive defense or a pathological reaction? Psychoanalytic Psychology, 24(2), 355-372. http://dx.doi.org/10.1037/0736-97 35.24.2.355

Received: August 17, 2017

Final version: January 21, 2018

Approved: March 6, 2018 